\title{
Sera Koşullarında İleri Patates Hatları ve Çeşitlerinin Mini Yumru Performanslarının Belirlenmesi
}

\author{
Ercan ÖZKAYNAK ${ }^{1}$, Tuğba ŞIMSŞEK ${ }^{1}$
}

ÖZET: İleri patates hatları ve çeşitlerinde doğrudan üretimde kullanılabilecek büyüklükte mini yumru (35mm'den büyük mini yumru büyüklüğü) elde edilmesine geniş sıra üzeri mesafenin $(40 \mathrm{~cm})$ etkisini belirlemek amacıyla sera koşullarında mini yumru denemesi kurulmustur. Araştırma Antalya'da sera koşullarında tesadüf blokları deneme desene göre yapılmıştır. İleri patates ıslah hatlarından, çeşitlere göre bitki başına mini yumru ağırlığı, ortalama mini yumru ağırlığı ve dekara doğrudan dikilebilir mini yumru ağıllığı değerleri bakımından daha yüksek değerler alınmıştır. Dekara doğrudan dikilebilir mini yumru sayısı en yüksek Concordia çeşidinde (517 24.52 adet) ve iki ileri hatta 12-16-104 (506 89.64 adet) ve 12-217-03 (496 55.70 adet) saptanmıştır. Bitki başına toplam mini yumru sayısı ve bitki başına doğrudan dikilebilir mini yumru sayısı değerleri tüm ortalama değerlere göre sırasıyla 12.03 adet ve 7.94 adet olarak bulunmuștur. Hatlar ve çeșitler ortalaması olarak doğrudan dikilebilir mini yumru oranı yaklaşı \%70 olarak bulunmuştur. Genel olarak bitki başına mini yumru sayısı ile bitki başına doğrudan dikilebilir mini yumru sayısı, dekara doğrudan dikilebilir mini yumru sayısı ve verimi arasında önemli pozitif ilişkiler bulunmuştur. Araştırmanın sonuçlarına göre sera koşullarında ileri ıslah hatları ve çeşitlerine ait in vitro şartlarda gelişen patates bitkileri geniş sıra üzeri mesafede etkili bir şekilde büyük boyutta tohumluk patates üretiminde kullanılabileceği belirlenmiştir.

Anahtar kelimeler: Korelasyon, mini yumru, Solanum tuberosum L., verim

\section{Determination of Minituber Performance of Advanced Potato Lines and Cultivars in Greenhouse Conditions}

\begin{abstract}
Potato minituber experiment was conducted in greenhouse conditions to determine the influence of wide in-row distance $(40 \mathrm{~cm}$ ) on directly planted seed size (minitubers bigger than $35 \mathrm{~mm}$ in size) minituber production in advanced potato breeding lines and cultivars. The research was carried out in Randomized Block Design in greenhouse conditions in Antalya. Advanced potato breeding genotypes gave a higher minituber weight per plant, average minituber weight and directly planted minituber weight per decare values than cultivars. The highest directly planted minituber number per decare were obtained from Concordia cultivar (517 24.52) and two advanced lines 12-16-104 (506 89.64) and 12-217-03 (496 55.70). For total minituber number per plant and directly planted minituber number per plant were found 12.03 and 7.94 respectively, all average values. The percentage of directly usable minitubers as a seed was found approximately $70 \%$ in average over the genotypes and cultivars. In general, significantly positive relationships were found between minituber number per plant and directly planted minituber number per plant, directly planted minituber number and yield per decare. These results of this study demonstrated that potato transplants of improved breeding genotypes and cultivars growing in wide row distance can be used effectively to expand production of big size potato seed stocks in greenhouse.
\end{abstract}

Keywords: Correlation, minituber, Solanum tuberosum L., yield

\footnotetext{
Ercan ÖZKAYNAK (0000-0002-4793-7963), Tuğba ŞİMŞEK (0000-0002-5947-2796), Yüksel Tohum Tarım San.. Tic. A.Ş., Ar-Ge Merkezi, Antalya, Türkiye

Sorumlu yazar/Corresponding Author: Ercan ÖZKAYNAK, eozkaynak@yukseltohum.com
} 


\section{GİRIŞ}

Bitki doku kültürü teknikleri yaklaşık 30 yıldır kültür bitkilerinde farklı amaçlar için etkin bir şekilde kullanılmaktadır. Özellikle patates gibi vejetatif olarak çoğaltılan bitkilerde doku kültürü tekniklerinden mikro çoğaltma ile çok sayıda hastalıksız bitki ve bu bitkilerden de tohumluk yumrular elde edilmektedir.

Patateste in vitro koşullarda geliştirilen bitkilerden üretilen mini yumrular tarla koşullarında 1-2 generasyon çoğaltılarak üretiminde kullanılabilecek tohumluk yumrular elde edilmektedir.

In vitro koşullarda mini yumru üretiminde; kültür süresi, bitki sayısı, eksplant büyüklüğü ve bitki büyüme düzenleyicileri gibi faktörler etkin rol oynamaktadır (Ahloowalia, 1994). In vivo koşullarda ise bitki yaşı, fidelikte gelişme koşulları, dikim zamanı, sezonu ve yöntemi, bitki sıklı̆̆1, büyüme süresi, sulama, gübreleme, hasat sıklığı ve zamanı gibi faktörler etkilemektedir (Farran and Mingo-Castel, 2006; Van der Veeken and Lommen, 2009; Sharma and Pandey, 2013).

Mini yumru üretimde 100-200 bitki m² sıklığ 1 gibi yüksek sıklıkta dikim ile hasat edilebilir seviyede az sayıda yumru elde edilmektedir. Patateste tekrarlamalı hasatlarda küçük mini yumrular elde edilmekte ve yoğun bir iş gücü gerekmektedir. Bu tip üretim şekli ticari üretimde pek kullanılmamakla birlikte küçük mini (3-9g) yumrular depolama aşamasında büyük yumrulara göre daha fazla ağırlık kaybı yaşamakta ve tarlaya dikimden sonra düşük performans göstermektedirler (Karafyllidis et al., 1997).

Son yıllarda ticari üretimlerde büyük mini yumruların ( $10 \mathrm{~g}$ ve üstü) üretimi tercih edilmektedir. (Van der Veeken and Lommen, 2009). Patateste mini yumru sayısı ve büyüklüğünü etkileyen bitki sıklığ1 mekanizmaları ile ilgili bilgilerin sınırlı olduğu ve yeni araştırmaların yapılması gerektiği bildirilmiştir (Van der Veeken and Lommen, 2009).

Araştırma üstün özelliklere sahip çeşit adayı ileri ıslah hatları ve bazı çeşitlerin in vitro koşullarda geliştirilen bitkilerinin sera koşullarında geniş bitki sıklığında tarlada doğrudan ticari üretimde kullanılabilecek büyüklükte mini yumru üretim kapasitesini belirlemek amacıyla yürütülmüştür.

\section{MATERYAL VE YÖNTEM}

Araştırma kapsamında 2008-2014 tarihleri arasında patateste Türkiye koşullarına uygun erkenci yemeklik patates çeşitleri geliştirmek amacıyla Antalya bölgesinde ve koşullarında 1slah çalışmaları başlatılmış ve adaptasyon çalışmaları farklı bölgelerde (Adana, Antalya, Afyonkarahisar, İzmir ve Niğde) yürütülmüştür. Islah çalışmaları sonucunda erkenci ve orta erkenci olum grubunda, bitki, yumru, verim ve kalite özellikleri yönünden üstün özellik gösteren 15 ileri patates hatt1 seçilmiştir. 15 ileri patates hattı ve 8 patates çeşidi (BIW, Concordia, Georgine, Milva, Obama, Saline, Synergy ve Volimia) araştırmada materyal olarak kullanılmıştır. In vitro koşullarda geliştirilmiş ileri patates hatları ve patates çeşitlerine ait stok bitkilerden alınan tek boğum eksplantları MS (Murashige and Skoog, 1962) besin ortaminda petri kutularında 2 hafta süreyle geliştirilmiştir. Bitkiler $\% 3$ sukroz ve \% 0.7 agar içeren besin ortamında büyütülmüştür (Şekil 1).

Besin ortamında bitki büyüme düzenleyicileri kullanılmamıştır. Kültürler doku kültürü büyüme odasında 16 saat 1 şı $\left(25 \pm 1{ }^{\circ} \mathrm{C}\right)$ ve 8 saat karanlık $\left(23 \pm 1{ }^{\circ} \mathrm{C}\right)$ ortamda büyütülmüştür. In vitro koşullarda 5-7 cm boyundaki bitkiler \% 10 vermikulit, \% 25 perlit ve \% 65 torf karışımı içeren viyollere şaşırtılarak fide yetiştirme serasına aktarılmıştır. Bitkiler kademeli olarak az sulanarak ilk 1-2 gün gölge, sonrasında az 1şıklı koşullarda büyütülerek alıştırma aşaması tamamlanmıştır. Bitkiler alıştırma aşaması ile birlikte 20 gün süreyle fide yetiştirme serasında viyollerde geliştirildikten sonra seraya dikilmiştir. Seraya $50 \mathrm{~cm}$ sıra arası ve $40 \mathrm{~cm}$ sıra üzeri mesafede dikilmiştir.

Araştırmada Antalya koşullarında seraya bitki dikimleri 28 Ağustos 2013 tarihinde yapılmış, hasat ise $25 \mathrm{Kas} 1 \mathrm{~m} 2013$ tarihinde gerçekleştirilmiştir. Araştırma elde edilecek mini yumruların dormansi kırıldıktan sonra bahar üretimlerinde kullanılabilmesi için özellikle sonbahar döneminde yapılmıştır. Sulama damlama sulama sistemi ile yapılmıştır. 


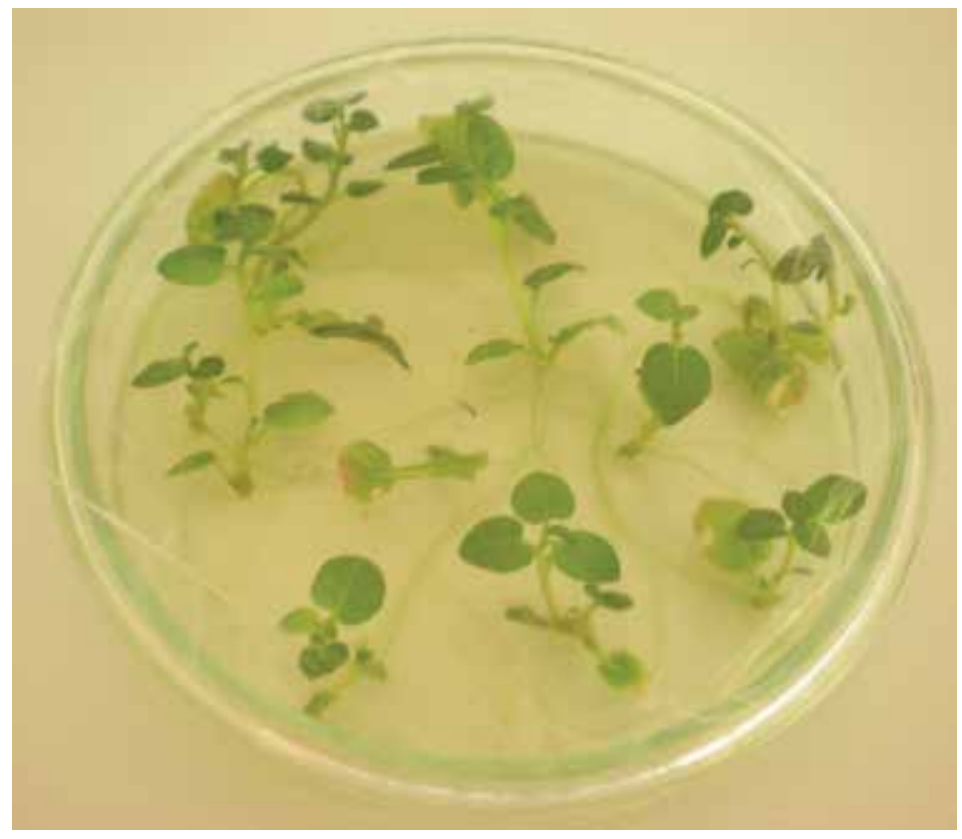

Şekil 1. In vitro koşullarda gelişmiş bitkiler

Dikimden önce 15:15:15 dengeli gübre kullanılmıştır. Yetiştirme süresince çiçeklenme dönemine kadar dengeli gübre, çiçeklenmeden sonraki aşamada 1:2:1 (N:P:K) içerikli gübre ve yumru büyüme döneminde de 1:1:3 içerikli gübreleme ile patates bitkileri yetiştirilmiştir. Araştırma sera koşullarında tesadüf blokları deneme desenine göre üç tekerrürlü olarak yürütülmüş ve her ileri patates hattı ve çeşitten her tekerrürde karşılıklı ikişer sira olacak şekilde 250 'şer bitki dikilmiştir. Hasattan sonra her tekerrürde rastgele seçilen 20 bitkiden veriler alınmıştır. Araştırma süresince sera içinde herhangi bir suni 1şıklandırma veya 1 sıtma yapılmamıştır. Bitkiler $18-32{ }^{\circ} \mathrm{C}$ sıcaklık aralığında büyümüşlerdir. Gece sıcaklığı $8{ }^{\circ} \mathrm{C}$ 'nin altına düşmemiştir. Nem oranı \% 60-80 seviyelerinde seyretmiştir. Gün uzunluğu seraya dikimde başlangıçta 15-17 saat iken hasat dönemine yakın zamanda 12-14 saat arasında değişim göstermiştir.

Araştırmada hasattan sonra bitki başına toplam mini yumru sayısı, bitki başına toplam mini yumru ağırlı̆̆ bitki başına ortalama mini yumru ağırlığı, bitki başına doğrudan dikilebilir (35-45mm iriliğinde mini yumru büyüklüğ̈̈) mini yumru sayısı, bitki başına doğrudan dikilebilir mini yumru ağırlığı ortalaması, dekara dikilebilir mini yumru sayısı ve mini yumru verimi özellikleri belirlenmiştir. Dekara verim hesaplamaları $1000 \mathrm{~m}^{-2}$ ye 5000 adet bitki dikimine göre yapılmıştır. Araştırmada elde edilen veriler MCTAT_C istatistik programı kullanılarak varyans analizine tabi tutulmuş, ortalama değerler LSD testi ile değerlendirilmiş ve özellikler arasında korelasyon katsayıları hesaplanmıştır (Freed et al., 1989).

\section{BULGULAR VE TARTIŞMA}

Araştırmada 1slah çalışmaları sonucunda geliştirilen 15 ileri çeşit adayı patates hattı ve çeşitlere ait mini yumru özellikleri Çizelge 1 'de verilmiştir. Çizelge 1 incelendiğinde bitki başına toplam mini yumru sayısı bakımından en yüksek değerler 17.6 adet ile Concordia ve Obama çeşitlerinde bulunmuştur. Bu çeşitleri Milva çeşidi, 12-217-03, 12-16-104 ve 12-01-128 hatları izlemiştir. Bitki başına en az yumru sayısı ise BIW, Synergy çeşitleri ve 12-40-08 hattında elde edilmiştir. Ortalama değer ise 12.03 adet olarak bulunmuştur. Bitki başına doğrudan dikilebilir mini yumru sayısı bakımından en yüksek değer 11.8 adet ile 12-16-104 hattında bulunmuş, bu hattı 10 adet ile Concordia çeşidi ve 9.6 adet ile 12-217-03 hattı takip etmiştir. En düşük değerler ise sirasıyla 5.0 ve 5.8 adet ile BIW ve Synergy çeşitlerinde elde edilmiştir. İleri çeşit adayı hatlar 6-9 adet arasında dikilebilir mini yumru sayısı verirken ortalama 7.94 adet olarak bulunmuştur.

Bitki başına toplam mini yumru ağırlığı ortalaması $822.10 \mathrm{~g}$ olarak bulunmuştur. En yüksek değerler 1082.80g ile 12-01-128 hattında bulunmuş, bu hattı 12-41-22, 12-40-08 ve 12-221-14 hatları izlemiştir. Çeşitlerden ise en yüksek değeri $965.6 \mathrm{~g}$ ile Concordia çeşidi vermiştir. En düşük değerler ise Synergy, Saline ve BIW çeşitlerinde elde edilmiştir. İleri çeşit adayı 
hatlar bitki başına toplam mini yumru ağırlı̆̆ olarak yaklaşık $750 \mathrm{~g}$ ve üstünde değerler vermişlerdir. Bitki başına doğrudan dikilebilir mini yumru ağırlı̆̆ 1 ortalaması bakımından en yüksek değerler Georgine çeşidinde ve 12-40-08 hattında bulunmuştur. Ortalama değer 109.05g olarak belirlenmiş, en düşük değerler ise Milva, Volimia, 12-16-104 ve Synergy çeşitlerinde elde edilmiştir. Ortalama mini yumru ağırlığı bakımından en yüksek değer 112.20 g ile 1240-08 hattında saptanmıştır. En düşük değerler ise Milva, Saline ve Obama çeşitlerinde bulunmuştur. İleri patates hatlarında ortalama mini yumru ağırlı̆ $60 \mathrm{~g}$ ve üstünde bulunurken genel ortalama $73.57 \mathrm{~g}$ olarak saptanmıştır.
Vosatka and Gryndler (2000) yaptıkları araştırmada $100 \times 40 \mathrm{~cm}$ 'lik tohum yataklarında (tohum yatağ başına 8 bitki) in vitro bitkilerden bitki başına 48.10-64.45g mini yumru ağırlığı, 7.63-9.63 adet mini yumru sayıs1 ve $5.60-8.45 \mathrm{~g}$ ortalama mini yumru ağırlı̆ 1 değerleri saptamışlardır. Pruski et al., (2003) patates bitkilerini tohum yatağına $9 \times 9 \mathrm{~cm}$ sıra aralığ yumru gelişimini incelemişlerdir. Araştırmada bitki başına mini yumru sayısı 2.22-3.95 adet, yumru ağırlığ1 $53.35-169.35 \mathrm{~g}$ arasında değişmiştir. Araştırmada bitki başına elde edilen mini yumru sayısı, ağırlığ ortalama mini yumru sayısı yönünden Vosatka and Gryndler (2000); Pruski et al., (2003)'a göre daha yüksek değerler elde edilmiştir.

Çizelge $1.40 \mathrm{~cm}$ bitki sıklığında ileri patates hatları ve çeşitlerde mini yumru özellikleri

\begin{tabular}{|c|c|c|c|c|c|c|c|c|}
\hline & $\begin{array}{c}\text { İleri Hatlar- } \\
\text { Çeşitler }\end{array}$ & $\begin{array}{c}\text { BBTMYS } \\
\text { (adet) }\end{array}$ & $\begin{array}{c}\text { BBTMYA } \\
\text { (g) }\end{array}$ & $\begin{array}{c}\text { OMYA } \\
\text { (g) }\end{array}$ & $\begin{array}{c}\text { BBDDMYS } \\
\text { (adet) }\end{array}$ & $\begin{array}{c}\text { BBDDMYAO } \\
\text { (g) }\end{array}$ & $\begin{array}{c}\text { DDMYS } \\
\text { (adet) }\end{array}$ & $\begin{array}{c}\text { DDMYV } \\
\text { (kg) }\end{array}$ \\
\hline 1 & $12-16-104$ & 14.40 & 751.60 & 61.07 & 11.8 & 80.19 & 50689.64 & 3887.58 \\
\hline 2 & $12-52-96$ & 11.20 & 799.60 & 73.68 & 9.0 & 91.66 & 46551.68 & 4163.79 \\
\hline 3 & $12-123-03$ & 10.20 & 693.60 & 68.88 & 7.40 & 99.62 & 38275.86 & 3587.58 \\
\hline 4 & $12-41-22$ & 11.60 & 1064.20 & 92.37 & 8.40 & 126.30 & 43448.23 & 5503.45 \\
\hline 5 & $12-40-08$ & 9.0 & 1004.80 & 112.20 & 7.60 & 150.70 & 39310.30 & 5197.24 \\
\hline 6 & $11-05-29$ & 12.0 & 791.60 & 66.76 & 6.80 & 121.80 & 35172.29 & 4094.48 \\
\hline 7 & $12-01-128$ & 14.0 & 1082.80 & 82.19 & 8.20 & 132.10 & 42413.58 & 5600.69 \\
\hline 8 & $12-60-27$ & 12.20 & 767.20 & 65.97 & 7.60 & 101.80 & 39310.33 & 3968.28 \\
\hline 9 & $12-221-14$ & 11.20 & 1004.80 & 90.44 & 8.60 & 122.0 & 44482.71 & 5197.24 \\
\hline 10 & $12-224-03$ & 9.4 & 742.0 & 78.57 & 6.60 & 103.40 & 37241.32 & 3717.93 \\
\hline 11 & $12-03-85$ & 12.60 & 936.80 & 77.47 & 8.40 & 113.10 & 43448.23 & 4845.51 \\
\hline 12 & $12-217-03$ & 14.6 & 979.60 & 67.28 & 9.60 & 102.10 & 49655.02 & 5081.38 \\
\hline 13 & $12-55-07$ & 12.60 & 924.80 & 73.79 & 8.60 & 109.40 & 44482.70 & 4783.45 \\
\hline 14 & $12-55-16$ & 9.60 & 899.20 & 99.17 & 6.80 & 133.70 & 35172.37 & 4651.04 \\
\hline 15 & $12-189-06$ & 9.80 & 861.60 & 90.09 & 7.80 & 110.20 & 40344.78 & 4456.55 \\
\hline 16 & BIW & 7.80 & 566.80 & 82.23 & 5.0 & 113.10 & 25862.04 & 2931.73 \\
\hline 17 & OBAMA & 17.60 & 819.2 & 48.47 & 8.60 & 94.72 & 44482.70 & 4239.31 \\
\hline 18 & VOLIMIA & 13.20 & 710.0 & 55.32 & 9.0 & 83.28 & 46551.68 & 3672.42 \\
\hline 19 & SYNERGY & 6.80 & 488.0 & 74.19 & 5.80 & 86.69 & 29999.97 & 2524.14 \\
\hline 20 & MILVA & 15.2 & 594.0 & 38.90 & 8.0 & 74.81 & 41379.28 & 3084.00 \\
\hline 21 & SALINE & 13.80 & 512.40 & 40.73 & 6.40 & 89.54 & 33103.42 & 2650.35 \\
\hline 22 & GEORGINE & 10.20 & 948.0 & 95.11 & 6.60 & 168.69 & 36206.82 & 4903.44 \\
\hline \multirow[t]{3}{*}{23} & CONCORDIA & 17.60 & 965.60 & 55.14 & 10.0 & 99.43 & 51724.09 & 4994.48 \\
\hline & Ortalama & 12.03 & 822.10 & 73.57 & 7.94 & 109.05 & 40839.52 & 4249.39 \\
\hline & $\operatorname{LSD}(0.01)$ & 2.483 & 102.60 & 12.72 & 1.20 & 18.49 & 3799.25 & 276.48 \\
\hline
\end{tabular}

BBTMYS: bitki başına toplam mini yumru sayısı, BBTMYA: bitki başına toplam mini yumru ağırlığı, OMYA: ortalama mini yumru ağırlı̆̆ı, BBDDMYS: bitki başına doğrudan dikilebilir mini yumru sayısı, BBDDMYAO: bitki başına doğrudan dikilebilir mini yumru ağırlığı ortalaması, DDMYV: dekara dikilebilir mini yumru verimi, DDMYS: dekara dikilebilir mini yumru sayısı 
Dekara doğrudan dikilebilir mini yumru sayıs1 bakımından en yüksek değerler Concordia çeşidinde (517 24.09 adet), 12-16-104 (506 89.64 adet) ve 12217-03 (496 55.02 adet) hatlarında saptanmıştır. En düşük değerler BIW, Snergy ve Saline çeşitlerinde belirlenmiştir. Ortalama olarak dekara yaklaşık 41000 adet doğrudan dikilebilir mini yumru sayıs1 değeri saptanmıştır. Dekara doğrudan dikilebilir mini yumru verimi en yüksek $5600.69 \mathrm{~kg}$ ile 12-01128 hattında elde edilmiş, bu hattı 12-41-22, 12-4008 ve 12-221-14 hatları izlemiştir. Dekara doğrudan dikilebilir mini yumru verimi çeşitlere göre $2500 \mathrm{~kg}$ ile $5200 \mathrm{~kg}$ arasında değişmiştir. En düşük değerler Synergy ve Saline çeşitlerinde elde edilmiştir. Ortalama olarak dekara doğrudan dikilebilir mini yumru verimi yaklaşık 4300kg olarak saptanmıştır.

Santos and Rodriguez (2008) patateste mikro yumrulardan filizlendirilen bitkileri açık tarlada 20, $25,30,35$ ve $40 \mathrm{~cm}$ sira üzeri mesafelere dikerek mini yumru verimlerini değerlendirmişlerdir. Bitki başına mini yumru ağırlığ 20 cm'de $195 \mathrm{~g} \mathrm{bitki}^{-1}$ iken $40 \mathrm{~cm}^{\prime}$ de $269 \mathrm{~g} \mathrm{bitki}^{-1}$ olarak gerçekleşmiştir. Hektara mini yumru sayıs1 ise $20 \mathrm{~cm}$ 'de 425000 adet iken $40 \mathrm{~cm}$ 'de 119000 adet olarak elde edilmiştir. Bitki başına mini yumru sayısı ise 20 ve $25 \mathrm{~cm}$ sıra üzeri mesafelerde 6.5 adet ortalama ile en yüksek bulunmuş ve en uygun sira üzeri mesafeler bu aralıklar olarak tavsiye edilmiştir. Araştırmada sera koşullarında Santos and Rodriguez (2008)'e göre dekardan daha yüksek mini yumru sayısı ve bitki başına mini yumru sayısı elde edilmiştir.

Patateste düşük bitki sıklığında mini yumru sayıs1, verimi ve ortalama yumru ağırlığı daha yüksek bulunurken, toplam yumru sayıs1 ve $\mathrm{m}^{-2}$ ye yumru sayısının bitki sıklığı artıkça arttığı belirlenmiştir (Gupta et al., 2003). Patateste 48 bitki $\mathrm{m}^{-2}$ bitki sıklı̆̆ında $\mathrm{m}^{-2}$ ye 24 bitki dikimine göre daha yüksek verim, daha yüksek çoğalma oranı ve daha yüksek mini yumru oranları elde edilmiştir (Wiersema et al., 1987). Hindistan'da kısa gün koşullarında serada $45 \times 10 \mathrm{~cm}$ bitki sıklığında bitki başına maksimum mini yumru sayısı ve verimi elde edilirken; 30x10 cm bitki sıklığında birim alan başına daha yüksek verim elde edilmiştir (Sharma and Pandey, 2013). Araştırmada 50x40 cm bitki siklığında araştırıcıların bulgularına benzer şekilde yumru sayısı ve ağırlığı artış göstermiş, dekardan elde edilen iri mini yumru sayısı da yüksek bulunmuştur.

Van der Veeken and Lommen (2009) ticari üretim koşullarında farklı bitki sıklıklarının mini yumru verim ve sayısına etkilerini araştırmışlardır. Araştırmada 3 farklı bitki sıklığı uygulaması (25, 62.5 ve 145.8 bitki $\left.\mathrm{m}^{-2}\right)$ incelenmiştir. Araştırmada düşük bitki sıklı̆g (seyrek dikim şartlarında) tüm mini yumru büyüklüklerinde bitki başına elde edilen yumru sayısını artırmıştır. Düşük bitki sıklığında $\mathrm{m}^{-2}$ 'den daha az sayıda mini yumru elde edilmesine rağmen yumru başına daha yüksek ağırlık elde edildiği için $\mathrm{m}^{-2}$ den elde edilen toplam yumru ağırlığında artış görülmüsşür. $\mathrm{Bu}$ araştırmada da benzer şekilde seyrek dikimde (50x40 cm) bitki başına daha az, ama doğrudan üretimde kullanılabilecek büyüklükte daha fazla mini yumru elde edilmiştir. Seyrek dikimlerde 1 şık, su ve besin elementleri yönünden bitkiler arasında daha az rekabet olduğundan bitki büyüme ve gelişmesi daha iyi olmaktadır.

Van der Veeken and Lommen (2009) yaptıkları çalışmada genel olarak serada yetiştirilen mini yumruların, yumru ağırlığına göre değil yumru sayısına göre satıldığı ve çapları 9mm'den büyük yumruların satılabilecek kadar büyük yumrular olduğu belirtilmiştir. Fakat $17 \mathrm{~mm}$ 'den büyük yumruların $9 \mathrm{~mm}$ olanlara göre daha iyi performans gösterdikleri için daha fazla tercih edildikleri de bildirilmiştir. Araştırma sonucunda düşük bitki sıklığında (seyrek dikimlerde) mini yumru üretiminin ticari derecede $(>9 \mathrm{~mm}$ ) daha fazla sayıda mini yumru üretimi için iyi bir uygulama olduğu ve bu yolla aynı zamanda daha yüksek ortalama yumru ağırlığ alanda 145.8 'den 25 'e düşürülmesi ile bitki başına iki kat daha fazla hasat edilebilir yumru elde edilirken ayn zamanda in vitro üretiminde kullanılan iş gücü-zaman ve alet-ekipman ihtiyacı da yarı yarıya düşmüştür. Buna rağmen bitki sıklığının 145.8 'den 25'e düşürülmesi m ${ }^{-2}$ başına elde edilen mini yumru sayısını 3 'te bir oranına düşürmüştür. Böylece $\mathrm{m}^{-2}$ ye 25 bitki dikildiğinde aynı sayıda mini yumru elde edebilmek için gerekli üretim alanının 3 kat daha fazla olması gerekliliği ortaya çıkmıştır. Bu durum da mini yumru üretim maliyeti tekrar artıracaktır. Yaptığımız araştırmada olduğu gibi geniş bitki sıklığında in vitro bitki üretiminde daha az iş yoğunluğu kullanılarak ve fazla sayıda mini yumruyu elde etmek için daha fazla üretim alanında daha kaliteli, doğrudan dikilebilecek irilikte mini yumrular elde edilebilecek ve ticari olarak daha yüksek fiyatla satılarak denge sağlanabilecektir.

Araştırmada 15 ileri çeşit adayı patates hattı ve 8 ticari çeşit kullanılmıştır. Üstün hatlardan ve çeşitlerden elde edilen mini yumru sayı, ağırlık ve verimleri farklılık 
göstermiştir. Araştırma bulguları ile uyumlu olarak mini yumru üretiminin genotipe önemli derecede bağlı olduğu ve çeşitlerin mini yumru üretim kapasitelerinin farklılıklar gösterdiği belirtilmiştir (Venkatasalam et al., 2011; Sharma et al., 2013). Yüksek ve düşük verimli çeșitler arasında mini yumru verimi bakımından 10 kata kadar farklılıkların olabileceği bildirilmiştir (Ahloowalia, 1994). Patates çeşitleri arasında serada in vitro bitkilerin gelişmesi, bitkilerin kapladığı alan, mini yumru sayısı ve verimi yönünden önemli farkl1lıkların olabileceği bildirilmiştir (Kumar et al., 2011).

Araştırmada mini yumru özellikleri arasındaki korelasyon katsayıları Çizelge 2'de verilmiştir. Korelasyonlar incelendiğinde bitki başına toplam mini yumru sayısı ile bitki başına doğrudan dikilebilir mini yumru sayısı, bitki başına toplam mini yumru ağırlığ 1 , dekara dikilebilir mini yumru sayısı ve verimi arasında pozitif, ortalama mini yumru ağırlığı ve dikilebilir mini yumru ağırlığı ortalaması arasında ise negatif yönde önemli ilişkiler bulunmuştur. Araştırmada elde edilen sonuçlarla uyumlu şekilde, Mojaradpour et al.,
(2012) patateste bitki başına mini yumru sayısı ile bitki başına mini yumru ağırlığ $1, \mathrm{~m}^{-2}$ ye mini yumru sayısı ve ağırlığı arasında pozitif yönde, ortalama mini yumru ağırlığ 1 arasında ise negatif yönde önemli korelasyonlar bulmuşlardır.

Doğrudan dikilebilir mini yumru sayısı ile ortalama ve dikilebilir mini yumru ağırlığı ortalaması arasında negatif, toplam mini yumru ağırlığı, dekara dikilebilir mini yumru sayısı ve verimi arasında ise pozitif ilişki bulunmuştur. Ortalama mini yumru ağırlığı ile bitki başına, doğrudan ve dekara mini yumru sayısı arasında negatif yönde önemli korelasyonlar bulunurken; doğrudan dikilebilir mini yumru ağırlığı ortalaması, bitki başına toplam mini yumru ağırlığı ve dekara dikilebilir mini yumru verimi arasında pozitif yönde önemli korelasyonlar elde edilmiştir. Benzer şekilde Khodadadi et al., (2011); Mojaradpour et al., (2012) patateste ortalama mini yumru ağırlı̆̆ ile $\mathrm{m}^{-2}$ ye mini yumru sayısı arasında negatif yönde önemli ilişkiler elde etmişlerdir.

Çizelge 2. Mini yumru özellikleri arasındaki korelasyon katsayıları

\begin{tabular}{|c|c|c|c|c|c|c|}
\hline & BBDDMYS & OMYA & BBDDMYAO & ВВТМYA & DDMYV & DDMYS \\
\hline BBTMYS & $0.640 * *$ & $-0.654^{* *}$ & $-0.237 * *$ & $0.324 * *$ & $0.328 * *$ & $0.604 * *$ \\
\hline BBDDMYS & & $-0.243^{* *}$ & $-0.427 * *$ & $0.413 * *$ & $0.416^{* *}$ & $0.921 * *$ \\
\hline OMYA & & & $0.573 * *$ & $0.402 * *$ & $0.397 * *$ & $-0.215^{*}$ \\
\hline BBDDMYAO & & & & $0.425^{* *}$ & $0.425 * *$ & $-0.425 * *$ \\
\hline BВTMYA & & & & & $0.996 * *$ & $0.501 * *$ \\
\hline DDMYV & & & & & & $0.504 * *$ \\
\hline
\end{tabular}

BBTMYS: bitki başına toplam mini yumru sayısı, BBTMYA: bitki başına toplam mini yumru ağırlığı, OMYA: ortalama mini yumru ağırlığı, BBDDMYS: bitki başına doğrudan dikilebilir mini yumru sayısı, BBDDMYAO: bitki başına doğrudan dikilebilir mini yumru ağırlığı ortalaması, DDMYV: dekara dikilebilir mini yumru verimi, DDMYS: dekara dikilebilir mini yumru sayısı

Bitki başına doğrudan dikilebilir mini yumru ağırlığ ortalaması, bitki başına mini yumru ağrıllı̆g ve dekara mini yumru verimi ile olumlu, dekara mini yumru sayısı ile olumsuz yönde önemli korelasyonlar göstermiştir.

Bitki başına toplam mini yumru ağırlığı ile dekara mini yumru verimi arasında pozitif yönde önemli korelasyonlar gösterirken; dekara dikilebilir mini yumru verimi de beklenildiği gibi, dekara dikilebilir mini yumru sayısı ile önemli ve olumlu korelasyon göstermiştir. Araştırma sonuçları ile uyumlu şekilde Khodadadi et al., (2011) mini yumru ile ilgili yaptıkları araştırmada $\mathrm{m}^{-2}$ ye mini yumru sayısı ile $3-7 \mathrm{~g}$ ve $>7 \mathrm{~g}$ mini yumru sayısı ve ağırlığı arasında pozitif yönde önemli korelasyonlar bulmuşlardır. $\quad \mathrm{M}^{-2}$ ye mini yumru sayısı ile ağırlığı arasında pozitif yönde önemli korelasyonlar bulunmuştur. 


\section{SONUÇLAR}

Araştırmada ileri patates hatları arasında bitki başına toplam mini yumru sayısı bakımından 12-21703, 12-16-104 ve 12-01-128 hatları, bitki başına toplam mini yumru ağırlı̆̆ bakımından 12-41-22, 12-40-08, 12-221-12 ve 12-217-03 hatları, bitki başına doğrudan dikilebilir mini yumru sayısı bakımından 12-16-104, 12-217-03 ve 12-52-96 hatları, bitki başına doğrudan dikilebilir mini yumru ağırlığı ortalaması yönünden 1240-08, 12-55-16, 12-01-128 hatlar1 dekara dikilebilir mini yumru sayıs1 yönünden 12-16-104 ve 12-21703 hatlar1; dekara dikilebilir mini yumru verimi bakımından ise 12-01-128, 12-41-22, 12-221-14 ve 12217-03 hatları ilk sıralarda yer almışlardır. Mini yumru özellikleri yönünden genel olarak yüksek değerleri Georgine ve Concordia çeşitleri vermiş ve birçok özellik yönünden üstün performans göstermişlerdir. Çeşitler arasında mini yumru özellikleri bakımından en düşük değerler Saline ve Synergy çeşitlerinde elde edilmiştir. Çeşit adayı üstün hatlar arasında 12-217-03, 12-40-08 ve 12-16-104 hatları mini yumru özellikleri yönünden üstün performans gösteren ticari olarak seçilebilecek çeşitler olarak değerlendirilmiştir.

Tohumluk patates üretiminde kullanılan mini yumrunun büyüklüğü, birim alandan elde edilecek yumrunun verim ve kalitesi bakımından çok önemlidir. Üretimde eğer küçük mini yumrular kullanılacaksa, tarla koşullarında mini yumru büyüklüğü küçük olduğu için bitkilerde çıkışta ve ilk gelişme dönemlerinde zayıf

\section{KAYNAKLAR}

Ahloowalia BS, 1994. Production and performance of potato minitubers. Euphytica, 75(3): 163-172.

Farran I, Mingo Castel AM, 2006. Potato minituber production using aeroponics: effect of plant density and harvesting intervals. American Journal of Potato Research, 83: 47-53.

Freed R, Einensmith SP, Guetz S, Reicosky D, Smail VW, Wolberg P, 1989. User's Guide to MSTAT-C Analysis of Agronomic Research Experiments. Michigan State University, USA.

Gupta VK, Kumar S, Baishya LK, Kumar M, 2003. Effect of planting density on mini-tuber production from micropropagated plants. Potato Journal, 30: 43-44.

Karafyllidis DI, Georgakis DN, Stavropoulos NI, Vezyroglou IA, Nianiou EX, 1997. Effect of planting density and size of potato minitubers on their yielding capacity. Acta Horticulturae, 462: 943-949. büyüme ve gelişmeden dolayı bazı problemler ortaya çıkabilmektedir. Serada $40 \mathrm{~cm}$ sıra üzeri mesafede doğrudan üretimde kullanılabilecek mini yumru elde etmek amacıyla yapılan bu çalışmada çeşit ve hatlar ortalaması yaklaşık olarak bitki başına toplam 12 yumru ve bunun da 8'i doğrudan tarlaya dikilebilecek büyüklükte olan mini yumru elde edilmiştir. Bir dekarlık bir sera alanından ortalama olarak 41000 adet civarında iri ve kaliteli mini yumru elde edilebilmektedir. Türkiye'de tohumluk patates ihtiyacı her geçen gün artmakta yeni çeşitlere ihtiyaç duyulmaktadır. $\mathrm{Bu}$ araştırmanın amacı, Türkiye koşullarına uygun, erkenci, verimli ve kaliteli üstün çeşit adaylarının geniş sıra aralığında mini yumru performanslarının değerlendirilmesi olmuştur. Bu amaç doğrultusunda geliştirilen ileri çeşit adaylarının ve çeşitlerin doğrudan tarlaya dikilebilecek büyüklükte mini yumru oluşturma potansiyeli belirlenmiştir. Araştırma sonucunda ileri patates hatlarında in vitro bitkilerden gelişen fidelerde sera koşullarında geniş sıra üzeri mesafede $(40 \mathrm{~cm})$ mini yumru üretimi yapılarak yaklaşı $\% 70$ oranında doğrudan tarlaya dikilebilecek büyüklükte mini yumru üretimi yapılabileceği sonucuna varılmıştır.

\section{TEŞEKKÜR}

$\mathrm{Bu}$ çalışmayı 3110172 nolu proje olarak destekleyen TÜBİTAK Teknoloji ve Yenilik Destek Programları Başkanlığı (TEYDEB)'e teşekkür ederiz.

Khodadadi M, Hassanpanah D, Pirovatlo SP, Masoumi H, 2011. Evaluation of different planting beds effects on mini-tuber production of potato cultivars under greenhouse condition. American Eurasian Journal of Agriculture and Environment Science, 11(3): 365-370.

Kumar D, Singh V, Singh BP, 2011. Growth and yield of potato plants developed from in vitro plantlets in nethouse. Potato Journal, 38(2): 143-148.

Mojaradpour R, Valizadeh M, Alizadeh B, Hassanpanah D, 2012. Evaluation of year and cultivar on mini-tuber production of potato (Solanum tuberosum L.) under destructive and nondestructive harvesting methods at greenhouse conditions. International Journal of Agronomy and Plant Production, 3(11): 550-556. 
Pruski K, Astatkie T, Duplessis P, Lewis T, Nowak J, Struik PC, 2003. Use of jasmonate for conditiong of potato plantlets and microtubers in greenhouse production of minitubers. American Journal of Potato Research, 80: 183-193.

Santos BM, Rodriguez PR, 2008. Optimum in-row distances for potato minituber production. HortTechnology, 18(3):403-406.

Sharma AK, Pandey KK, 2013. Potato mini-tuber production through direct transplanting of in vitro plantlets in green or screen houses. Potato Journal, 40(2): 95-103.

Sharma AK, Venkatasalam EP, Kumar V, 2013. Potato mini-tuber production during main and off crop seasons in high hills of north-western Himalaya. Potato Journal, 40(1): 29-37.

Van der Veeken AJH, Lommen WJM, 2009. How planting density affects number and yield of potato minitubers in a commercial glasshouse production system. Potato Research, 52: 105-119.
Venkatasalam EP, Latawa J, Sharma S, Sharma S, Sharma AK, Sharma S, Patial R, Singh S, 2011. In vitro and in vivo performance of potato cultivars for different seed production systems. Potato Journal, 38(2): 149-154.

Vosatka M, Gryndler M, 2000. Response of micropropagated potatoes transplanted to peat media to post-citro inoculation with arbuscular mycorrhizal fungi and soil bacteria. Applied Soil Ecology, 15: 145-152.

Wiersema SG, Cabello R, Tovar P, Dodds JH, 1987. Rapid seed multiplication by planting into beds micro-tubers and in vitro plants. Potato Research, 30(1): 117-120. 